\title{
International terrorism, domestic coverage? How terrorist attacks are presented in the news of CNN, Al Jazeera, the $B B C$, and ARD
}

the International

Communication Gazette 2014, Vol. 76(I) 3-26

(C) The Author(s) 2013 Reprints and permission: sagepub.co.uk/journalsPermissions.nav DOI: 10.1 I77/|7480485|3504/58 gaz.sagepub.com

(S)AGE

\section{Jürgen Gerhards}

Institute of Sociology, Free University of Berlin, Germany

\section{Mike S Schäfer}

Institute of Mass Communication and Media Research - IPMZ, University of Zurich, Switzerland

\begin{abstract}
The article analyzes to what extent news reporting on terrorist attacks globalized, regionalized, or country specific. We compare coverage on four terrorist incidents in the main news shows of the US edition of CNN, of Al Jazeera's Arabic language service, of the British BBC, and of the German ARD. The analysis shows cross-national similarities in several dimensions: the analyzed media devote nearly identical amounts of attention to the four events, employ similar stylistic devices to describe them, and evaluate them similarly. At the same time, there are notable differences. These differences are not found between Western channels and Al Jazeera - as proponents of a 'clash of civilizations' might expect but between CNN and Al jazeera on the one hand, and the BBC and ARD on the other. The former interpret the attacks as an expression of a global "war on terror", whereas the latter see them as criminal attacks by a few individuals against the human civilization itself.
\end{abstract}

\section{Keywords}

Al Jazeera, framing, globalization, mass media, news coverage, television, terrorism

\section{Corresponding author:}

Mike S Schäfer, Institute of Mass Communication and Media Research - IPMZ, University of Zurich, Andreasstr. I5, CH-8050 Zurich, Switzerland.

Email: m.schaefer@ipmz.uzh.ch 


\section{Introduction'}

Terrorism has become an international phenomenon (cf. Schneckener, 2006): terrorists operate in not just one but many different countries, the terrorist threat is no longer perceived by citizens and politicians as being nationally bounded but as a global issue (Beck, 1999; Borgeson and Valeri, 2008; Müller, 2008), and the geographical scope of anti-terrorist measures has expanded (Münkler, 2005).

Terrorist action can be defined as the intentional use of physical force by non-state actors against 'soft targets' such as 'civilians' (cf. Townshend, 2002: 11; Tuman, 2003), but it is more than an act of violence. It also has to be understood as a 'communication strategy in which messages are sent in a spectacular way' (Münkler, 2005: 177) ${ }^{2}$ to elites and populations. The distribution of these messages depends strongly on mass media, which extend the reach of terrorism far beyond the city or country in which an attack has been carried out and makes the inherent threat perceptible to a broader audience (Fuchs, 2004: 79). The extent and the nature of media constructions are, therefore, significant catalysts of terrorist events. Mass media draw attention to certain attacks and present them in specific ways (cf. Weimann and Brosius, 1991), make them appear relevant to citizens (Borgeson and Valeri, 2008: 128), may influence individual and institutional decision making (cf. Oates, 2006), and contribute to the (de)legitimation of certain political movements (cf. Scheufele et al., 2005).

Within the media landscape, television plays a particularly important role, as it is widespread and commonly used in many countries (cf. Hans-Bredow-Institut, 2009; IP International Marketing Committee, 2008). Furthermore, due to its audio-visual character and the possibility of live reporting, it can provide timely and (supposedly) realistic depictions of terrorist events (Hoffman, 2007: 276).

The aim of this study is to investigate the specifics of mass media representations of terrorism. We analyze these specifics in a comparative study because it enables us to determine the specific domestic features of such representations. Since international terrorism has been interpreted and structured primarily in terms of the ongoing conflict between the Arab and 'Western' worlds (cf. Rapoport, 2006), we examine news broadcasts from both sides of this alleged conflict: the 'Evening News' of the US service of CNN, 'Hasad Al Yaum' from Al Jazeera's Arabic service, the 'Ten O'clock News' from British BBC One and the 'Tagesschau' of German public broadcaster ARD. In doing so, we will go beyond the existing literature on terrorism coverage which consists primarily of case studies of individual countries (cf. Cohen-Almagor, 2005; Woods, 2007) and only a handful of comparative studies (cf. Oates, 2006; Papacharissi and de Fatima Oliveira, 2008). By including Al Jazeera, we extend the scope of our analysis beyond the commonly investigated 'Western' context. Moreover, we do not analyze print media, as is frequently done elsewhere (cf. Altheide, 2006; Schaefer, 2003), because their significance often remains limited, especially in regions with high rates of illiteracy. Instead, we focus on TV coverage, i.e., on probably the most relevant medium for a comparative analysis of terrorism coverage.

\section{Theoretical framework}

There are different theories in communication and social sciences as to whether and to what extent the reporting of different TV channels in different countries might be similar 
or along which lines they might differ. From these assumptions, three theorems can be drawn which we will use as heuristics to guide the interpretation of our analysis. ${ }^{3}$

\section{Country-specific reporting}

Some scholars assume that media coverage is mainly influenced by national contexts. Accordingly, coverage would be expected to vary considerably from country to country. The domestic factors influencing media reporting have been systematized by Shoemaker and Reese (1995) as well as Weischenberg $(1992,1995)$, in a model of concentric circles of influence on media coverage. The outer circle consists of a country's historical and cultural characteristics which may differ according to national traditions of journalism (Esser, 1998: 25), geographical or linguistic particularities (Thomaß, 2007: 23), religious differences (Hafez, 2005a: 148), or the differing value systems of political elites (cf. Bennett, 2009; Bennett et al., 2006). The next layers of influence consist of countryspecific structural, institutional and organizational characteristics such as economic factors, technological influences (Weischenberg, 1992: 249, 1995: 13) or typical working processes in newsrooms (Esser, 1998: 26). In the inner circle, we find sociodemographic characteristics, attitudes, self-perceptions and motivations of journalists (Esser, 1998: 26). It is assumed that the characteristics and relevance of these factors vary from country to country, and that coverage on external or transnational issues, such as international terrorism, is molded by them into a specific, domestic view (Swanson, 2003: 57). This model corresponds with the significant country differences that have been shown in media coverage on issues like abortion (Ferree et al., 2002), biotechnology (Schäfer, 2007) or European Union enlargement (e.g. Wimmel, 2006).

\section{Regional patterns in reporting}

Other scholars suggest that cross-national variance may be subordinate to regional differences in media reporting. Two variants of this perspective can be distinguished.

(a) In line with the structural pattern of contemporary terrorism, which is often perpetrated by Arab Islamists against 'Western' victims, some scholars expect the strongest differences between the coverage in Western and Arab media. Most often, these assumptions are rooted in alleged cultural differences or, in turn, similarities. Some scholars draw on Samuel Huntington's controversial thesis of a "clash of civilizations" (1998, for critical accounts see Bantimaroudis and Kampanellou, 2007; Barber, 1995) to underline their claims. Huntington has posited that the 21 st century world is characterized by opposing "cultures," especially by the conflict between the Christian-dominated "West" with the US as its "core" state, and the "Islam" residing primarily in the Arab world. He argues that this conflict finds its expression, among other aspects, in the public rejection or devaluation of the other side (Huntington, 1998: 345); and accordingly, differences between "Western" and Arab media reporting might be expected (cf. Seib, 2004: esp. 79 ff.). Coming from an entirely different theoretical background, research on the role of cultural proximity in media reporting leads to similar assumptions: it has been argued that cultural proximity functions as a news value, i.e. meaning that culturally proximate issues and aspects are more likely to be taken up and highlighted by 
journalists (see Galtung and Ruge, 1965), and that similar preferences can be found among culturally similar audience members (Ksiazek and Webster, 2008). These theories, similar to Huntington in this respect, lead to assumed differences in terrorism coverage between Western and Arab media. Comparative studies have indeed found such differences and mutual stereotyping, for instance in media coverage on the September 11 attacks, the Afghanistan and Iraq wars, the "image of Islam" in Western media, or inversely in the presentation of the "West" in Arab media (cf. Abrahamian, 2003; Aday et al., 2005; Hafez and Richter, 2007; Jasperson and El-Kikhia, 2003). While some scholars explain differences between Western and Arab media with cultural factors, others suggest that similar differences can be ascribed to differences in the respective media system. Comparative media systems' analyses show clear differences between Western and Arab countries. While western media systems are classified as liberal (like the US) or socially responsible and public service-oriented (like the UK or Germany, Blum, 2005 and Siebert et al., 1963), Arab media systems are seen as more authoritarian (Rugh, 2007; Selber and Ghanem, 2004) even if they are currently undergoing rapid change and differ from each other internally (cf. Iskandar, 2007; Rugh, 2007).

(b) Regional differences in coverage may also be assumed because the analyzed countries and regions are involved in crucial conflicts to different degrees. It has been argued that a part of a journalists' profession is to provide a "national outlook" (Nossek, 2004: 349 ), so that nationally significant events tend to be discussed in more detail. News value theory provides a simple explanation for this phenomenon, and empirical studies show that terrorist events are interpreted by journalists as more or less 'newsworthy' and covered accordingly (Kelly and Mitchell, 1981; Weimann and Brosius, 1991). Nossek's thesis that the interpretation of a terrorist event as "ours" or "theirs" influences its media representation $(2004,2008)$ fits well into this theory (for a similar account see Nacos, 2007). Accordingly, it can be assumed that differences between groups of countries need not (only) be culturally determined, but that the participation of countries in specific conflicts will also be reflected in media coverage. Since contemporary terrorism is fueled by the conflicts in Palestine, Iraq, and Afghanistan, and because countries like the US, UK, and Germany are involved to different degrees in these conflicts, this can be expected to affect their coverage.

\section{Global standardization of coverage}

In contrast to theories emphasizing country or regional differences in media coverage, many scholars emphasize the similarities among media constructions worldwide, and relate these to globalization (cf. critical: Hafez, 2005b; Herman and McChesney, 2000; Luhmann, 1997; Thompson, 2000). Partly as a result of an "increase in formal and informal communication links that connect the international, national and regional news media with each other" (Swanson, 2003: 69), it has been argued that a "transnational news culture" (Cohen et al., 1990: 44), a "global newsroom" (Gurevitch and Levy, 1990; Gurevitch et al., 1991) or a "global news system" (Swanson, 2003: 69) can be found nowadays. This global standardization is seen to be particularly strong in visual media such as television, which overcome spatial and temporal boundaries more easily than print media (Hallin and Mancini, 2004: 56; Löffelholz and Hepp, 
2002: 15), and in reporting about 'global problems' (Krotz, 2005: 34) such as climate change (Ivanova et al., ; Schmidt et al., 2013) or international terrorism which are globally relevant (cf. Beck, 1999).

In the case of terrorism coverage, several authors have demonstrated how such similarities manifest themselves: Norris et al. (2003) argue that a worldwide normative assessment has been established with regard to terrorism: attacks are to be rejected by political elites almost everywhere, even by (former) leaders of countries like Libya, Syria, and Iran which, according to intelligence services, may be secretly supportive of terrorism (cf. Townshend, 2002: 12; Tuman, 2003: 6). Norris et al. argue that the condemnation of terrorism has become part of a 'global script,' in the sense of Meyer (2005) that has to be supported - at least officially - by all nation states and expressed by the United Nations in several resolutions (cf. UN General Assembly, 2006: 3). Norris and colleagues go on to assume that this script would also be characteristic for media coverage, in which the portrayal of terrorism would then become standardized across countries and, thus, a "one-sided" case' (Norris et al., 2003: 12). The attacks and their perpetrators are condemned and compassion is shown for the victims. The assumed connection between media coverage and the views of political elites corresponds to Bennett's Indexing Theory (1990; see also Robinson, 2001). In times of international conflict, he argues, the constellation of actors in the media environment, especially the positioning of political elites, plays a particularly large role in shaping the coverage (see also Altheide, 2006; Oates, 2006). Accordingly, a consensus among elites about the importance and the evaluation of a subject would strongly be reflected in the media. In turn, when political elites were divided, this would lead to a pluralization of media positions. These findings seem to be consistent with the US coverage of the conflicts in Afghanistan and Iraq. Within the US political elites there was an initial consensus on the legitimacy of military interventions resulting in a largely consistent portrayal across the range of US media. But this consensus was not shared by the political elites of other countries, especially in the Arab world. Accordingly, Jasperson and El-Kikhia (2003) found significant differences between CNN and Al Jazeera in their evaluation and interpretation of the Afghanistan war, and Aday et al. (2005) provide similar findings for coverage of the Iraq war.

Table 1 provides a summary of the different theories we have discussed. In the following sections, we will use them as means to interpret our empirical findings.

\section{Data and methods: Analyzing the main news of CNN, Al Jazeera, the BBC, and ARD}

\section{Data selection}

The selection of our data followed a hierarchical logic. First, we decided to analyze television coverage, as television is the most common and intensively used mass medium in most countries around the world including Arab and Western countries (cf. Arab Statistics, 2009; IP International Marketing Committee, 2008), and particularly so in extreme events such as terrorism (Emmer et al., 2002: 169). Second, we chose TV broadcasters which represent different countries and regions of the world, and which are relevant due to their scope and impact: the US service of $\mathrm{CNN}$, the pan-Arab station Al Jazeera 
Table I. Theoretical assumptions concerning the shape of terrorism coverage in different countries.

\begin{tabular}{|c|c|c|c|c|}
\hline \multirow[b]{2}{*}{$\begin{array}{l}\text { Central } \\
\text { heuristic }\end{array}$} & \multirow{2}{*}{$\begin{array}{l}\text { Country-specific } \\
\text { coverage } \\
\text { Importance of the } \\
\text { Nation-state/ } \\
\text { 'Onion model' }\end{array}$} & \multicolumn{2}{|c|}{$\begin{array}{l}\text { Regional/cultural } \\
\text { differences }\end{array}$} & \multirow{2}{*}{ 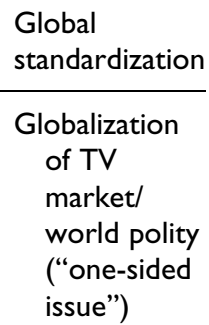 } \\
\hline & & $\begin{array}{l}\text { "Clash of cultures" } \\
\text { vs. Cultural } \\
\text { Proximity }\end{array}$ & $\begin{array}{l}\text { Involvement in } \\
\text { international } \\
\text { conflicts }\end{array}$ & \\
\hline $\begin{array}{l}\text { What is } \\
\text { expected? }\end{array}$ & $\begin{array}{l}\text { Coverage is } \\
\text { country-specific }\end{array}$ & $\begin{array}{l}\text { Coverage is similar/ } \\
\text { different according } \\
\text { to geographical and } \\
\text { cultural regions }\end{array}$ & $\begin{array}{l}\text { Coverage is } \\
\text { similar/different } \\
\text { according to } \\
\text { involvement in } \\
\text { a conflict }\end{array}$ & $\begin{array}{l}\text { Coverage is } \\
\text { standardized } \\
\text { globally }\end{array}$ \\
\hline Why? & $\begin{array}{l}\text { Media embedded in } \\
\text { different national } \\
\text { contexts }\end{array}$ & $\begin{array}{l}\text { Fundamental cultural } \\
\text { differences or } \\
\text { proximities }\end{array}$ & $\begin{array}{l}\text { Different } \\
\text { involvement in } \\
\text { central conflicts }\end{array}$ & $\begin{array}{l}\text { Global reach of } \\
\text { technology, } \\
\text { worldwide } \\
\text { problems }\end{array}$ \\
\hline $\begin{array}{l}\text { What is } \\
\text { expected } \\
\text { for our } \\
\text { comparison? }\end{array}$ & All channels differ & $\begin{array}{l}\text { Arab and Western } \\
\text { channels differ }\end{array}$ & $\begin{array}{l}\text { Different levels } \\
\text { of involvement } \\
\text { lead to } \\
\text { coverage } \\
\text { differences }\end{array}$ & $\begin{array}{l}\text { All channels } \\
\text { are similar }\end{array}$ \\
\hline
\end{tabular}

(Qatar), BBC One (UK) and the German ARD (see table 2). ${ }^{4}$ Third, we analyzed the main daily news programs of these channels, which are especially suited for comparative analysis (Rössler, 2004: 271) as they have large audiences and are perceived as high quality, informative and credible by most audience members (cf. Al Jazeera, 2009; Office of Communications, 2008: 51; Pew Research Center, 2004; Zubayr and Geese, 2009).

We investigated these channels' coverage of four terrorist attacks. In line with our conceptual framework, we selected incidents in Madrid, London, Amman, and Sharm El Sheikh (see Table 3), i.e., attacks in both Western and Arab countries that involved primarily Western and primarily Arab victims, as well as attacks on locals and foreigners. All of these took place within a relatively short period of time, in 2004 and 2005.

\section{Data analysis}

Up to 7 days of coverage following the attacks were included in our analysis. De facto, 87 news shows and 658 individual news segments were investigated using a combination of qualitative and quantitative content analyses. ${ }^{5}$

The quantitative content analysis covered the basic features of the analyzed footage, such as the date and length of transmission, and format. ${ }^{6}$ It also covered the importance given to an event by the broadcasters, the weight assigned to the event in relation to others (placement within the transmission, scope, etc.), and how the event was evaluated. Finally, we assessed how the victims (the number of the dead and injured, how many 
Table 2. Overview of the selected broadcasters and their news programs. ${ }^{a}$

\begin{tabular}{|c|c|c|c|c|}
\hline & CNN & Al Jazeera & BBC & ARD \\
\hline Headquarters & $\begin{array}{l}\text { Atlanta } \\
\text { (USA) }\end{array}$ & $\begin{array}{l}\text { Doha } \\
\text { (Qatar) }\end{array}$ & London (UK) & $\begin{array}{l}\text { Munich (GER), } \\
\text { "Tagesschau" } \\
\text { from Hamburg } \\
\text { (GER) }\end{array}$ \\
\hline $\begin{array}{l}\text { Domestic } \\
\text { reach }\end{array}$ & $84 \%$ & $\begin{array}{l}\text { Pan-Arabic } \\
\text { (for example, } \\
\text { Jordan } 72 \% \text { and } \\
\text { Saudi Arabia } 82 \% \text { ) }\end{array}$ & $100 \%$ & $100 \%$ \\
\hline $\begin{array}{l}\text { Domestic } \\
\text { market } \\
\text { share }\end{array}$ & $\begin{array}{l}22 \% \text { "regular } \\
\text { viewers" } \\
(2004)\end{array}$ & $\begin{array}{l}\text { "most popular } \\
\text { channel" }\end{array}$ & $22.9 \%(2007)$ & I3.4\% (2008) \\
\hline $\begin{array}{l}\text { News } \\
\text { program }\end{array}$ & "Evening News" & "Hasad Al Yaum" & $\begin{array}{l}\text { “Ten O'clock } \\
\text { News” }\end{array}$ & “Tagesschau” \\
\hline
\end{tabular}

${ }^{a}$ The data were compiled on the basis of Al-Awsat (2006), IP International Marketing Committee (2008: 177, 435, 438, 462 f.), Lynch (2006: 45), Pew Research Center (2004, 2005, 2006), and Zubayr and Gerhard (2009: 103).

of these were shown in the images, as well as their gender, occupation, origin, and religion) and perpetrators (including their motives and objectives) were portrayed.

All news items were then analyzed qualitatively. This step - similar to many variants of qualitative research - aimed to condense and structure the source material (in the form of text and images) in terms of the research questions and theoretical assumptions (cf. Mayring, 1994; Miles and Huberman, 1994; Ritchie and Lewis, 2003). The analysis was an iterative process of data interpretation, category formation, relating categories to new material and categories, etc. (cf. Strauss, 1987). In this respect, Mayring (1994) distinguishes between summarizing, contextualization, and structuring of the material. Our approach is based on Mayring's method and will be specified in the following.

After transcribing the characteristics of the broadcasts in terms of language, sound, imagery, and technical details (choice of camera angles, etc.), the first analytical step was the creation of a basic protocol for each broadcaster and each day. Early in the project, these protocols were created by the entire research group of five. Later, they were written by one team member and subsequently reviewed, possibly corrected, and edited by a second member. Deductively (on the basis of research questions) and inductively (based on the qualitative coding of the coverage), the following categories were established as being useful for the description of coverage: (i) significance (the presented importance of the event), (ii) evaluation (how is the event evaluated?), (iii) victims (which victims of the attack are depicted and how?), (iv) perpetrators (which perpetrators are depicted and how?), (v) motives and objectives (how are the motives and targets of the perpetrators described?), (vi) reactions (what kinds of reactions to the event are shown and how?), and (vii) emotional representations (what emotions are represented and how?).

In a second step, synthesis protocols were written. The aim was to create a typological structure for the information contained in the basic protocols. In this process, broadcaster-specific and event-specific interpretations were added and cross-links and 


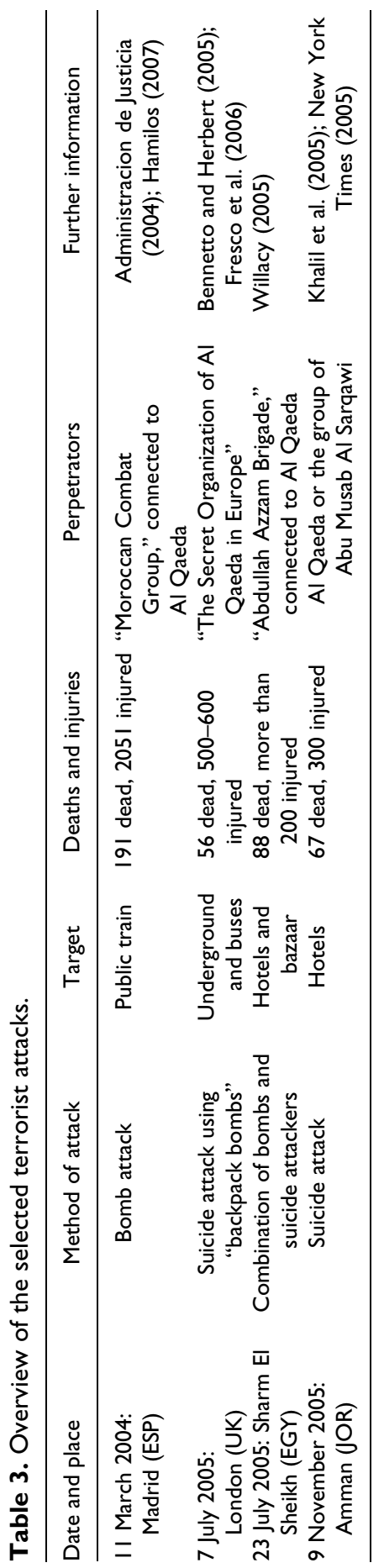


comparisons were integrated into the protocols. In turn, the amount of supporting materials such as quotations and images was reduced to typical examples. As with the basic protocols, the synthesis protocols were structured in terms of the dimensions described above, but adding a category in which the key interpretative pattern of a given terrorist incident was established. We tried to determine these underlying organizing ideas or patterns in "frames" (cf. Jasperson and El-Kikhia, 2003; Liebes and First, 2003; Norris et al., 2003; Schaefer, 2003) that were generated inductively; using the seven analytical dimensions described above in which one can often see a broadcaster's typical manner of representing a given attack. These frames are specific configurations of how the terrorist events were portrayed, what causal interpretations were provided, what moral evaluations were used, and what treatment recommendations were given - mirroring the dimensions of framing outlined by Entman (1993).

In a first step, the team member who had written the basic protocol of a channel's footage on a specific attack compiled the respective synthesis protocol. It was then corrected and adjusted by another team member who had previously watched the respective broadcasts. Discrepancies in interpretation between the two team members were resolved with recourse to the original broadcast and/or discussed with the entire research team. All established synthetic protocols were discussed by the entire research group afterwards and, if necessary, modified and supplemented. Discrepancies were again resolved with recourse to the material.

In total, 16 synthesis protocols were created for the analysis (four terrorist events covered by each of the four broadcasters). Each group member was involved at all stages of the process. The research group consisted of social scientists with competences in methodology, political communication, and comparative research, as well as necessary cultural competences for which purpose an Iraqi, a researcher trained in Arab studies, and another in American studies took part.

\section{Results}

Key similarities and differences between the analyzed TV stations will be presented along three dimensions: first, we will describe the significance that was assigned to the analyzed four terrorist incidents by the media - 'agenda setting' research shows, after all, that the significance with which an event is depicted in the mass media is reflected in the perceptions of the recipients (e.g. Hasebrink, 2006). Second, we will reconstruct the way in which the broadcasters depict the perpetrators and victims. Third, we will show how the events are framed.

\section{Similarities across all channels: Terrorism as significant and "one-sided"}

The first main finding of our study is that the terrorism coverage of CNN, Al Jazeera, the $\mathrm{BBC}$, and ARD show considerable similarities. These become clear, first of all, in the broadcasters' attribution of importance to the individual terrorist attacks. All channels devote almost identical amounts of attention to the four attacks. Despite the large number of terrorist attacks globally - the Rand Corporation database (2009) points to 2723 attacks between 1999 and 2008 - the four broadcasters portray the London, Madrid, and 
Table 4. Number of days on which the attacks were covered by the four broadcasters.

\begin{tabular}{lcccc}
\hline & CNN & Al Jazeera & BBC & ARD \\
\hline London & 6 & 7 & 7 & 7 \\
Madrid & 6 & 7 & 6 & 7 \\
Amman & 6 & 6 & 3 & 3 \\
Sharm El Sheikh & 3 & 4 & 4 & 4 \\
\hline
\end{tabular}

Sharm el Sheikh bombings on the same number of days within the first week, with the Amman bombing being the only visible deviation (see Table 4). Likewise, the amount of airtime devoted to these incidents and their placement within the news programs also show strong similarities.

The evaluation of the attacks - the "moral evaluation" component of media frames (Entman, 1993: 52) - was almost identical across all broadcasters. They clearly condemn the attacks and emphasize the illegitimacy of terrorism, even if the broadcasters - as we will discuss later - differ in the strength of their condemnation. These negative evaluations are manifested, first, in rhetoric: attacks and perpetrators are described as "brutal" (BBC, 8 July 2005), "barbaric" (Al Jazeera, 8 July 2005), " "hateful" or "criminal" (ARD, 7 July 2005, 10 July 2005), "insane" (CNN, 12 November 2005), and "atrocity" and "shocking" (BBC, 10 November 2005). Underlining these negative evaluations is a second feature used by all broadcasters and for all events: high-ranking individuals and commentators, such as US President George W Bush, British Prime Minister Tony Blair, UN General Secretary Kofi Annan or Jordan King Abdullah II, condemn the act. Third, the illegitimacy of the attacks is stressed further by highlighting the innocence of the victims and by representing them as uninvolved politically, militarily, and economically, i.e., as civilians who, regardless of religion or ethnicity, deserve sympathy. For example, the BBC highlights the "simple Londoners" (7 July 2005) that were attacked, and that in Amman, "innocent life" (BBC, 10 November 2005) and "innocent civilians" (Kofi Annan, ARD, 11 November 2005) were hurt or killed. Al Jazeera declares that the "attacks [in Amman] made no distinction between people with different political positions or between men, women and children" (11 November 2005). ${ }^{8}$ Finally, a fourth stylistic device is found across all stations: the juxtaposition of carefree everyday individual victims before the deed with their pain and suffering caused by the attacks, which underlines the negative evaluation of the attacks. This is most evident in the presentation of the attacks in Amman, where all stations reported on a wedding that was ended violently by the suicide bombings. Showing footage of the happy couple taken immediately before the attack, and contrasting this with the destroyed scene afterwards, CNN commenced its "Evening News" broadcast on the day of the attack in this way: "We begin tonight with a strong and simple lesson in terror. Terror has a wedding celebration transformed into a blood bath" (9 November 2005). The other stations also used this technique: "Five minutes after the start of the celebration all that was white is red" (Al Jazeera, 11 November 2005); "The party was going well. [...] This is AshrafEl Haled and his bride with their fathers - two proud men who were about to die" (BBC, 10 November 2005); or "They were just celebrating as the first explosive device went off” (ARD, 10 November 2005). A similar portrayal was visible with regard 
to the London bombings, where the Londoners' joy about being awarded the 2012 Olympic Games was contrasted with their shock about the bombings which followed shortly thereafter.

\section{Differences in coverage: The interpretive framework}

Apart from these similarities, however, there are also differences between the analyzed media. For example, even though the victims of the attacks are portrayed similarly on all channels, there are differences in the frequency of this representation. Similarly, the perpetrators and their motives, as well as possible or expected reactions to the acts, appear to different extents in the analyzed news shows. Such differences can be found in the basic definition of the terrorist incidents - or as the framing literature would say, in the "problem definition" - as well as its "causal interpretation" and the respective "treatment recommendations" (see Entman, 1993: 52 ff.). As we will see, there are even some, albeit small differences to be found in the "moral evaluation" dimensions. Overall, these varying emphases give rise to two different frames which are used by two broadcasters each.

The "war on terror" frame of CNN and AI Jazeera. CNN and Al Jazeera differ from the other channels in their interpretation of the attacks. They portray them as an expression of a geopolitical conflict in which the liberal Western democratic societies under US leadership on the one hand are confronted with transnationally organized Islamist terror networks, particularly Al Qaeda, on the other (cf. Reese and Lewis, 2009).

This interpretive framework becomes obvious through the choice of words and pictures: both broadcasters use explicit and often warlike vocabulary to describe the conflict and visualize the events with scenes from the Iraq and Afghanistan wars such as moving tanks or other military equipment. They also argue that countries like Britain and Jordan have become targets of terrorist attacks because they are "staunch American allies" (CNN, 9 November 2005; Al Jazeera, 7 July 2005). They do not interpret the attacks in local, regional, or national terms, but within a global context and often visualize this by using a world map of international terrorism or "modern war" - a stylistic device used by both CNN and Al Jazeera.

Moreover, the geopolitical framing of the terrorist attacks is manifested in a specific presentation of the victims, perpetrators, and overall reactions to the attacks. As mentioned previously, the difference in the representation of the victims by CNN and Al Jazeera in comparison to the other channels does not lie in the manner but in the extent of the victims' portrayal - both CNN and Al Jazeera show pity for the victims and portray them as innocent civilians but these representations are far less prominent than in the respective $\mathrm{BBC}$ or ARD coverage. While the latter stations portray the fates of individual victims in length on the first day of reporting on the London attacks, CNN and Al Jazeera only do so after a few minutes of discussion of the perpetrators. This can also be substantiated quantitatively: $\mathrm{CNN}$ and Al Jazeera depict victims in only a small percentage of their news segments ( $2.3 \%$ and $4.2 \%$, respectively), whereas the share for the BBC is $18.2 \%$ and for the ARD $33.3 \%$. The proportions of news segments talking about the death tolls of the attacks are similar (CNN 39.5\%, Al Jazeera 48.3\%, BBC 81.8\%, ARD 66.7\%). 
Instead, the perpetrators are focused on much stronger in CNN's and Al Jazeera's coverage. The origin and group affiliation of the (alleged) terrorists is reported extensively, as is speculation about their motives. Both on CNN and Al Jazeera, underlying motives are linked mainly to British and US foreign policy, whose "hostile invasion" was met with "massive resistance" in Iraq, "bringing the battle field into the countries that participated in the campaign" (Al Jazeera, 8 July 2005).

Finally, both CNN and Al Jazeera focus strongly on the consequences and reactions to the attacks, and in doing so, pay less attention to domestic investigations, clean-ups or rescue missions than on foreign policy reactions and, at times, military implications. Again, the geopolitical situation structures the coverage. $\mathrm{CNN}$ has a more aggressive style in which foreign policy preferences and options for military action are clear. The question is: "what can be done to stop it from happening again" (CNN, 7 July 2005), and George W Bush is quoted as saying: "In the face of such adversaries there is only one course of action: We will continue to take the fight to the enemy. And we will fight until this enemy is defeated!" (CNN, 11 July 2005). Al Jazeera, too, focuses mostly on geopolitical responses to the attacks. For example, the channels news anchors and experts discuss in detail how Tony Blair should be interpreted when he spoke of the need to show strength and fight terrorism "from its roots" (Al Jazeera, 8 July 2005). This is done cautiously and from a more defensive position but is often accompanied by fears of sweeping and exaggerated reactions.

There are further sub-distinctions between CNN and Al Jazeera which go back to their different evaluations of the geopolitical situation. With CNN, the legality of US actions with respect to the Western alliance and the illegitimacy of terrorist attacks are not drawn into question. The attacks are condemned strongly ("horror," 7 July 2005; "carnage," 9 July 2005; “insane,” 12 November 2005; "'barbaric," 9 November 2005; “diabolic," 10 November 2005) and the perpetrators are described in pejorative words (Al Qaeda as a "hydra-headed movement," 7 July 2005 and splinter groups as "cancer metastasis of Al Qaeda," 13 July 2005). CNN deals at length with the identification of the perpetrators but not with individual offenders and their personal motives; instead they are rather interested in the "enemy" terrorist networks. Moreover, in describing them as "British-based radical Muslims" (CNN, 7 September 2005) the CNN 'classify' the perpetrators not only in terms of their nationality but also in terms of their religion. The quantitative analysis reveals that in $30.2 \%$ of CNN's reports on Amman the religion of the perpetrators is mentioned (Al Jazeera 12.5\%, BBC 18.2\%, ARD 16.7\%).

Altogether, Al Jazeera represents the perpetrators in as much detail as the CNN, but does so differently: first, Al Jazeera devotes more airtime to the perpetrator's own perspective. It also gives them an individual face by allowing people from their communities to speak, people who understand their backgrounds ("What can you expect from people who are persecuted and are constantly threatened with death? [They] are constantly attacked with rockets, like in Falluja and Anbar,"; 9 November 2005). Second, Al Jazeera clearly distinguishes between the perpetrators and Muslims in general, and stresses, for example, that "Many Muslims have condemned the attacks" (9 July 2005; see 8 July 2005). Third, in some cases Al Jazeera implicitly blames Western elites, partly implicating them as co-culprits: Tony Blair and George W Bush, in Iraq and Afghanistan, "acted mercilessly against an enemy" (Al Jazeera, 7 July 2005). This, it 
is argued, is reciprocated in the form of terrorism in Britain and the United States. Generally, however, Al Jazeera focuses more than other stations on the illegitimacy of the foreign policy of the United States and its allies, which represents a failure (a "lost war," 8 July 2005, and "mistake," 7 July 2005) and they speculate, for example, on whether the British would withdraw their military from Iraq (10 July 2005).

In the presentation of the victims, several other specifics of Al Jazeera's coverage can be found. The channel is the only one that describes occasions where Muslims were victims of discrimination in the West. On the day of the London bombings, for example, they claim that the "Arab council in London [had] received threatening letters from strangers" and also ask: "Should one be worried about Arabs and Muslims in Britain?" (see 7 July 2005 and 13 July 2005). Similar statements can be found with respect to the attacks in Amman: Al Jazeera stressed that events "again illustrated the situation of the Palestinians. The wedding party [in the attacked hotel] was meant to reunite a family that had been separated since the 1967 war. The wedding became a funeral" (Al Jazeera, 11 November 2005). The victims are thus framed as victims in a double sense: they are shown to suffer under the Israeli occupation as well as from the attacks in Amman - suggesting a shared guilt for Israel and the United States (cf. Seib, 2004: 80).

Overall, however, these differences are arranged into a frame of interpretation $\mathrm{Al}$ Jazeera shares with CNN, Both interpret the attacks as expressions of a global political conflict - one in which their constituencies are strongly involved and often seen as the main conflict parties. In this way, they differ from the BBC and ARD.

"Crimes against humanity" - the frame of the BBC and ARD. The geopolitical interpretation of the terrorist attacks is considerably less pronounced in the coverage of the BBC and ARD. Instead, the attacks tend to be interpreted as criminal acts, with the conflict parties not being national governments and transnational terrorist organizations, but individual perpetrators and their victims which represent a multi-ethnic and multi-religious society.

This interpretive framework is manifested primarily in the fact that the representation of victims by the BBC and ARD is the most important reporting dimension in terms of length and placement. The detailed representation of the individual life-worlds of victims, which can be seen to some extent across all events, is clearly the central focus for the $\mathrm{BBC}$ and ARD. This is complemented by numerous references to the various ethnicities and religions to which the victims belong ("black and white, Muslim and Christian, Hindu and Jew, young and old," BBC, 7 July 2005, and "all colors, all races, all religions," ARD, 11 July 2005). On several occasions, both channels also show ethnically diverse groups or crowds mourning. Altogether, this presentation suggests that the attacks struck a cosmopolitan civil society or even the entire "human civilization" (ARD, 10 July 2005).

In contrast, the representation of the perpetrators receives very little attention and differs strongly from that of the $\mathrm{CNN}$ and Al Jazeera. The BBC and ARD are very careful about potential prejudice in their identification of the perpetrators. While both mention parallels between earlier Al Qaeda attacks and the London bombings, for example, they consistently point out that the authenticity of two letters of responsibility is yet to be proven. Throughout the broadcasts, they carefully choose their words. The broadcasters rely on information provided by official agencies of the government, but do not assert their 
own positions ("the BND claims that there is every indication that this is an attack with an Islamic background," ARD, 7 July 2005). They also sometimes present contradictory statements without taking a definite position, such as "the police do not currently have concrete evidence of the perpetrators. Tony Blair, however, is clear: "We know that these people act in the name of Islam"' (ARD, 7 July 2005). Furthermore, both broadcasters clearly distinguish between the perpetrators and other Muslims, noting, for example, that "the overwhelming majority of Muslims here and abroad are honest and law abiding people which abhor this kind of terrorism just as we do" (ARD, 7 July 2005).

This rather 'civil' (and less geopolitical) interpretation of the BBC and ARD is also manifested in the fact that the political motives of the perpetrators are less often mentioned and are less speculated upon. The hotels destroyed in the attacks on Amman, for example, are described as "big hotels" (BBC, 11 November 2005) or "luxury hotels" (ARD, 13 November 2005), and not as "American owned" (CNN, 9 November 2005) or hotels which are primarily frequented by Israeli tourists (Al Jazeera, 12 November 2005). In turn, the motives of the perpetrators remain rather vague in the coverage by the $\mathrm{BBC}$ and $\mathrm{ARD}$ - it is merely understood as an assault by a few extremists on "civilization" (ARD, 11 March 2004; 12 March 2004).

The same is true of the representation of the reactions to the attacks. The BBC and ARD present some of the potential geopolitical implications of the events, but do so with care and also focus much stronger on immediate local reactions such as rescue operations: "A large contingent of rescue forces were on the spot within a very short time. Support to hundreds of injured went well, stakeholders and police say" or "shortly after the explosions police began to evacuate the stations" (ARD, 7 July 2005; 8 July 2005). In addition, the consequences of the attacks on people's daily lives are presented in detail. Again and again, the broadcasters refer to the fact that terrorism will not succeed - we "cannot allow the perpetrators of violence, to destroy [British] society and values" (Tony Blair, ARD, 7 July 2005), "our way of life" will not change (Queen Elizabeth II, ARD, 8 July 2005), and "the terrorists will not bring us to our knees" (German Interior Minister Otto Schily, ARD, 8 July 2005). This mentality of resilience is also presented in the description of the "calmness of the crowds" (BBC, 7 July 2005) and the "incredible peace and serenity" of London (ARD, 7 July 2005). We see people on the day of the attacks who have to walk home or brave overcrowded trains, ferries, roads, and hotels, struggling to accept their fate. Calmly, "they want to send a message to the terrorists that life continues" (BBC, 8 July 2005). Moreover, the representation of a variety of expressions of solidarity and compassion by citizens, journalists, and elites evokes the image of a shared identity: "The world's reaction is mainly one of sympathy, solidarity and condemnation [,] those bombings brought civilized people closer together" (BBC, 11 July 2005).

\section{Summary}

Figure 1 summarizes the similarities and differences between the analyzed broadcasters interpretative frameworks schematically. Our comparative analysis of TV news coverage has shown that, on the one hand, the reporting of terrorism in different countries and regions has many similarities. CNN, Al Jazeera, the BBC, and ARD devote nearly identical amounts of attention to the four attacks, and the stylistic devices used to describe 


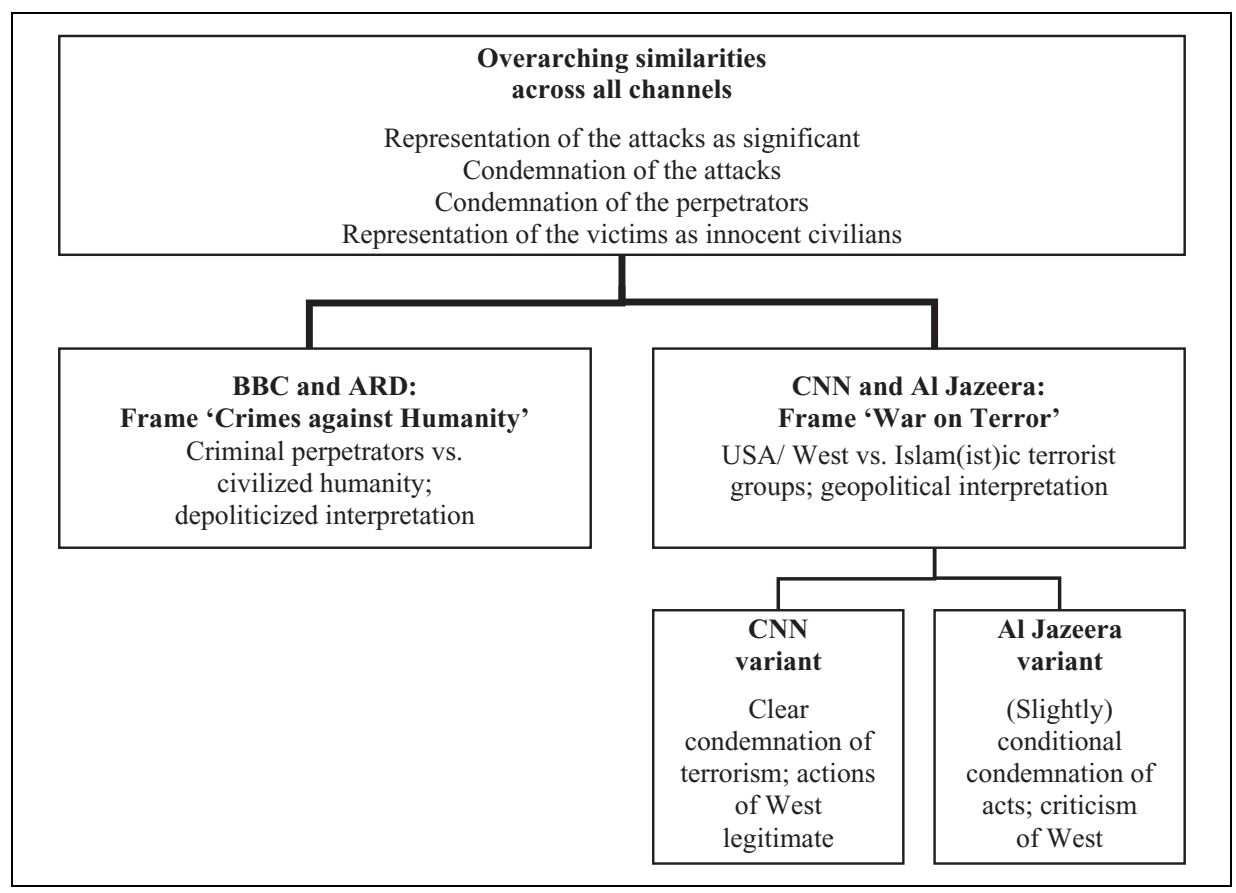

Figure I. Similarities and differences in the representation of terrorism.

them are very similar regardless of where the events took place and regardless of the location of the broadcaster. The evaluation of the actions of the perpetrators and the attitude towards the victims are also similar across all four channels. The attacks are uniformly condemned, and the victims are presented as innocent civilians who were unjustly injured or killed and deserve everybody's sympathy. In this regard, all of the channels underline the illegitimacy of the terrorist attacks. In this sense, we find a cross-national standardization of terrorism coverage which corresponds to the theoretical model of a "global standardization of coverage" outlined above.

On the other hand, we also found differences in the coverage. These lie mainly between the $\mathrm{CNN}$ and Al Jazeera on the one hand-i.e., between the broadcasters whose countries or regions are intensively involved in certain geopolitical conflicts - and the BBC and ARD on the other. The former interpret the attacks as an expression of a global "war on terror," whereas the latter see them as criminal attacks by a few individuals against civilization itself.

Relating our findings to the theories presented at the beginning of the paper, the overall results paint a mixed picture. In addition to some cross-broadcaster similarities, we find differences between CNN and Al Jazeera, on the one hand, and the BBC and ARD on the other. Even though we cannot explain these differences systematically, we consider factors outside the media to be the most important influences on terrorist coverage and, thus, the described similarities and differences. 
First, the far-reaching similarities in evaluation may be due in large mainly to the constellation of actors surrounding the media, especially to the political elites. A consensus in the evaluation and interpretation of terrorism is likely to lead to similar media presentations - and in turn, differences between media will increase if elites are divided (e.g. Bennett, 1990; Robinson, 2001). This is particularly true in conflicts, and particularly so in international conflicts. In the case of terrorism, there is a strong consensus on the illegitimacy of terrorist attacks (Norris et al., 2003: 12), which is not confined to individual nation states and not only to the 'West', but, at least officially, is supported throughout the world. This can be understood as part of a world culture which is codified by the decisions of the United Nations (cf. UN General Assembly, 2006: 3). Under these conditions, the mass media's evaluation of a topic can be expected to be largely uniform because there are no high-status actors from outside the media who publicly approve of the terrorist acts.

The nuancing in the evaluations, which differs between Al Jazeera and other broadcasters, could be explained as follows: under conditions of a hegemonic interpretation of events, dissent must be concealed through indirect means of articulation. They would first be formulated by actors of low social standing and are rarely expressed by large institutionalized media outlets. Second, evaluations which diverge from the hegemonic opinion shift to subtleties, to overtones and emphases. This is precisely what we found. Al Jazeera gives the perpetrator's perspective a little more time, discussing family background, thematizing more strongly the illegitimacy of the foreign policies of the US and its allies in Iraq and Afghanistan or the Israel-Palestine conflict, and reporting on a second group of victims - Muslims in the West who were targeted in the wake of the attacks. Thus, the negative assessment of the terrorist attacks, while extant, is mitigated slightly.

Nevertheless, the existence of such a consensus cannot account for the different frames we found, i.e. why CNN and Al Jazeera interpret the events as a "war on terror," while the BBC and ARD interpret them as "crimes against humanity." We suspect that these differences are due to country differences in the political landscape and in the positions of political elites in particular (Bennett, 1990; Nossek, 2004, 2008). The decisive factor seems to be the extent to which political actors interpret the attacks as an expression of a conflict in which one's own country is involved. In this respect, the stakeholders from outside the media differ in their evaluations, which corresponds with the interpretive framework that can be found in the mass media:

(a) In the US, the attacks of 11 September 2001 brought about a radical reorientation of foreign policy towards the "war on terror." At the same time, George W Bush appealed to all countries to support this effort, and interpreted the absence of assistance as an endorsement of terrorism: "Every nation [...] now has a decision to make. Either you are with us, or you are with the terrorists" (The White House, 2001). This bipolar standpoint has led to changes in US foreign policy and also reoriented and reorganized the national perception and interpretation of conflicts in Afghanistan, Iraq and elsewhere. This has been shown for a number of US media in the past (e.g. Cook, 1994; Hallin, 1994; Mermin, 1999) and corresponds with the dominant interpretative framework of CNN.

(b) The German government's position deviates markedly from the interpretation of US foreign policy. Although the attacks of 11 September 2001 were strongly condemned, Germany did not become directly involved in the 'war on terror,' refusing, for 
example, to participate in the Iraq War. The interpretation of the threats as well as the scope of foreign policy is much more moderate in German than US politics. Though CNN's interpretation of the examined events reflects official US policy, it seems that ARD's interpretive framework also takes its cue from German politics.

(c) The UK, in this respect, act ambivalent. On the one hand, the Blair government was, after 11 September, the closest ally of the US and their foreign policy, participating in the military interventions in Afghanistan and Iraq. At the same time, there was a growing and widespread social opposition across the UK which called attention to the negative consequences and lack of legitimacy of the wars (Williams, 2004). This situation, Robinson (2001) claims, created a window of opportunity for the media to position themselves. The BBC might well have used this opportunity in the cases we analyzed: the British prime minister and his cabinet members are given a voice, the attacks are not interpreted as an episode of the "war on terror," but as "crimes against humanity." The broadcaster, therefore, reflects the position of the British population more closely, which ranged from skeptical to critical of the Blair government's foreign policy stance.

(d) As a pan-Arab broadcaster, Al Jazeera cannot be assigned to any particular Arab country, which makes reference to a specific constellation of policy difficult. However, Al Jazeera has been characterized as critical towards Arab governments. This applies both to Arab countries that are US allies, such as Saudi Arabia, Kuwait and Qatar, as well as those who are more likely to be classified as opponents of US foreign policy like Syria or Iran. In this situation, it can be assumed that Al Jazeera reflects less the positions of certain Arab elites than, as Robinson (2001) suggests, its own unique position. As with the BBC, Al Jazeera's position has many parallels with the views of the Arab populations of many countries - the so-called "Arab street" (Center for Strategic Studies, 2005; Lynch, 2003).

Similarities and differences between broadcasters may not only be linked to constellations of actors outside the media but also traced back to media-specific factors, even though we think this is less plausible. In terms of journalistic cultures ("journalistic practices, professional standards and ethical factors"; for an overview see Hahn et al., 2008), there are many similarities between the television stations we have analyzed (cf. Hanitzsch and Seethaler, 2009; Küng-Shankleman, 2000; Miles, 2005). However, even if we consider it plausible that external media factors can explain the described differences and similarities better than media-specific differences, we are not able to prove this. This seems to be a worthwhile goal for future studies in the field of terrorism studies.

\section{Acknowledgments}

The authors would like to thank Ishtar Al Jabiri, Juliane Seifert, Antje Glück and Florian Eschenbacher, who contributed to the research presented here, as well as Inga Ganzer, who helped in preparing the manuscript for publication.

\section{Funding}

The project from which the study emerged was funded by the German Research Foundation in the framework of the Federal Cluster of Excellence 'Languages of Emotion.' 


\section{Notes}

1. Both authors contributed equally to the text; their names were listed alphabetically. A detailed description of the design, methodology and findings of the study as well as reports on other dimensions can be found in Gerhards et al. (2011).

2. This quote, as well as several others from German books and articles, has been translated into English for this publication.

3. We will not be able to 'test' them as terrorism coverage is determined by many factors; in our analysis, we are able to track and control a few of them only, and must therefore limit ourselves to the description of relatively few cases (cf. Lieberson, 1991). We will, however, identify factors that might provide an explanation to our findings at the end of the article.

4. Due to restrictions on availability of archival material, we were not able to include all the broadcasters we were initially interested in. As a result, we were only able to include the pan-Arab station Al Jazeera, rather than other Arab national broadcasters. We selected CNN and Al Jazeera because, unlike BBC and ARD, they are not general entertainment channels and broadcast only news. However, we analyzed only the main daily news programs of CNN and Al Jazeera as we assume that the most important events of the day are summarized in these broadcasts and which enables a comparison with the daily news programs of the general broadcasters.

5. For acquisition of material we used the archives of the German public broadcasters and the "Mediathek" of the ARD, the "BBC Motion Gallery," and the Television News Archive of the Vanderbilt University in Nashville. The material from Al Jazeera was gathered while visiting the station in Doha (Qatar).

6. The code book was based on conceptual considerations and classifications of other projects (e.g. Haußecker, 2007; Unz et al., 2008; Wirth, 2000) as well as comparative content analysis on other subjects or other types of media (Gerhards and Schäfer, 2006; Schäfer, 2007) and was then supplemented inductively on the basis of our material.

7. All quotes from Arabic were translated by Ishtar Al-Jabiri.

8. Sympathy for the victims is conveyed on all channels by allowing their relatives to speak. "There was a huge flash, an explosion, a lot of smoke. The train stopped, as did the oncoming train. There was lots of shouting" (ARD, 7 July 2005). "I found the whole room destroyed," sobs this woman. "My two daughters lay on the ground - dead" (CNN, 10 November 2005). "Everyone was screaming, I was screaming, I thought I'm gonna die. It was horrific" (BBC, 8 July 2005). In addition, journalists describe the individual fates of victims: "Yvonne is exhausted from the search;' "Also killed on the number 30 bus was Phillip Russell;' "Her boyfriend phoned his office minutes before the blast to say he was on the bus [and] hasn't been heard of since" (BBC, 8 July 2005; 12 July 2005). They present people "in the search for their relatives" (Al Jazeera, 8 July 2005) and their emotions ("We will not give up hope on Laura;' "No firm news either for Rosenberg's partner John. He has begun to mourn, to accept that she is dead,' BBC, 12 July 2005).

\section{References}

Abrahamian E (2003) The US Media, Huntington and September 11. Third World Quarterly 24: $529-544$. 
Aday S, Livingston S and Hebert M (2005) Embedding the truth: A cross-cultural analysis of objectivity and television coverage of the Iraq war. Harvard International Journal of Press/ Politics 10: 3-21.

Administracion de Justicia (2004) Juzgado Central de Instrucción $n^{\circ}$ 6, Audiencia Nacional. Madrid: Administracion de Justicia.

Al-Awsat, Asharq (2006) Leading Arab Television Stations Reject Zogby Report Available at: www.zogby.com/Soundbites/readclips.cfm?ID=12502 (accessed 10 December 2012).

Al Jazeera (2009) Al Jazeera Reaching 140 Million Viewers in the Arab World (Press Release, 31 st October 2009). Doha: Al Jazeera.

Altheide DL (2006) Terrorism and the politics of fear. Cultural Studies - Critical Methodologies 6: 415-439.

Arab Statistics (2009) Culture, information and communication technologies. Paris: Unesco. Available at: http://www.uis.unesco.org/Communication/Documents/ICT-arab-states-en. pdf

Bantimaroudis P and Kampanellou E (2007) The cultural framing hypothesis: Attributes of cultural alliances and conflicts. Harvard International Journal of Press/Politics 12: 80-90.

Barber BR (ed) (1995) Jihad vs. McWorld. How Globalism and Tribalism are Reshaping the World. New York: Ballantine Books.

Beck U (1999) World Risk Society. Cambridge: Polity Press.

Bennett WL (1990) Toward a theory of press-state relations in the United States. Journal of Communication 40: 103-125.

Bennett WL (2009) Power and the News Media: The Press and Democratic Accountability. In: Marcinkowski F and Pfetsch B (eds) Politik in der Mediendemokratie (Sonderheft der Politischen Vierteljahresschrift). Wiesbaden: Verlag für Sozialwissenschaften, pp. 84-102.

Bennett WL, Lawrence RG and Livingston S (2006) None dare call it torture: Indexing and the limits of press independence in the Abu Ghraib Scandal. Journal of Communication 50: 467-485.

Bennetto J and Herbert I (2005) London bombings: The truth emerges. The New Zealand Herald. Available at: www.nzherald.co.nz/london-bombings/news/article.cfm?c_id=1500947\&object $\mathrm{id}=10340636$

Blum R (2005) Bausteine zu einer Theorie der Mediensysteme, Medienwissenschaften Schweiz 2005(1-2): 5-11.

Borgeson K and Valeri R (eds) (2008) Terrorism in America. Boston: Jones and Bartlett.

Center for Strategic Studies (2005) Revisiting the Arab Street. Research from Within. Amman: University of Jordan/Center for Strategic Studies.

Cohen-Almagor R (2005) Media coverage of acts of terrorism: Troubling episodes and suggested guidelines. Canadian Journal of Communication 30: 383-409.

Cohen AA, Adoni H and Bantz CR (1990) Social Conflict and Television News. Newbury Park, CA: Sage.

Cook TE (1994) Domesticating a Crisis: Washington newsbeats and network news after the Iraqi invasion of Kuwait. In: Bennett WL and Paletz DL (eds) Taken by Storm: The Media, Public Opinion, and U.S. Foreign Policy in the Gulf War. Chicago, IL: University of Chicago Press, pp.105-130.

Emmer M, Kuhlmann C, Vowe G, et al. (2002) Der 11. September - Informationsverbreitung, Medienwahl, Anschlusskommunikation. Media Perspektiven 2002: 166-177. 
Entman RM (1993) Framing: Towards clarification of a fractured paradigm. Journal of Communication 43(4): 51-58.

Esser F (1998) Die Kräfte hinter den Schlagzeilen. Englischer und deutscher Journalismus im Vergleich. Freiburg \& München: Alber.

Ferree MM, Gamson WA, Gerhards J, et al. (2002) Shaping Abortion Discourse. Democracy and the Public Sphere in Germany and the United States. Cambridge: Cambridge University Press.

Fresco A, McGrory D and Norfolk A (2006) Video of London suicide bomber released. The Times Online, 7 June 2006.

Fuchs P (2004) Das System “Terror”. Versuch über eine kommunkative Eskalation der Moderne. Bielefeld: Transcript.

Galtung J and Ruge MH (1965) The structure of foreign news. The presentation of the Congo, Cuba and Cyprus crises in four Norwegian newspapers. Journal of Peace Research 2: 64-91.

Gerhards J and Schäfer MS (2006) Die Herstellung einer öffentlichen Hegemonie. Humangenomforschung in der deutschen und US-amerikanischen Presse. Wiesbaden: Verlag für Sozialwissenschaften.

Gerhards J, Schäfer MS, Al Jabiri I, et al. (2011) Terrorismus in den Medien. Formate, Inhalte und Emotionen in westlichen und arabischen Sendern. Wiesbaden: Verlag für Sozialwissenschaften.

Gurevitch M and Levy M (1990) The global newsroom. British Journalism Review 2: 27-37.

Gurevitch M, Levy M and Roeh I (1991) The global newsroom: Convergences and diversities in the globalisation of television news. In: Dahlgren P and Sparks C (eds) Communications and Citizenship: Journalism and the Public Sphere in the New Media Age. London: Routledge, pp. 195-212.

Hafez K (2005a) Globalization, regionalization and democratization: The interaction of three paradigms in the field of mass communication. In: Hackett RA and Zhao Y (eds) Democratizing Global Media. One World, Many Struggles. Lanham: Rowman \& Littlefield Publishers, pp. 145-163.

Hafez K (2005b) Mythos Globalisierung. Warum die Medien nicht grenzenlos sind. Wiesbaden: Verlag für Sozialwissenschaften.

Hafez K and Richter C (2007) Das Islambild von ARD und ZDF. Aus Politik und Zeitgeschichte 2007: 40-46.

Hahn O, Schröder R and Dietrich S (2008) Journalistische Kulturen. Forschungstypologie und Aufriss. In: Hahn $\mathrm{O}$ and Schröder R (eds) Journalistische Kulturen. Internationale und Interdisziplinäre Theoriebausteine. Köln: von Halem, pp. 7-30.

Hallin DC (1994) We keep America to the World. New York: Rouledge.

Hallin DC and Mancini P (2004) Americanization, globalization \& secularization. In: Esser F and Pfetsch B (eds) Comparing political communication: theories, cases, and challenges. Cambridge: University Press, pp. 25-44.

Hamilos P (2007) The worst Islamist attack in European history. The Guardian, 31 p. 7 October 2007. Hanitzsch T and Seethaler J (2009) Journalismuswelten: Ein Vergleich von Journalismuskulturen in 17 Ländern. Medien \& Kommunikationswissenschaft 57: 464-483.

Hans-Bredow-Institut (ed) (2009) Internationales Handbuch Medien. Baden-Baden: Nomos.

Hasebrink U (2006) Agenda-setting. In: Hans-Bredow-Institut (ed) Medien von A bis Z. Wiesbaden: Verlag für Sozialwissenschaften, pp. 19-21.

Haußecker N (2007) Zur Berichterstattung über Terrorismus in TV-Nachrichtensendungen am Beispiel der Terroranschläge in Kenia. Munich: GRIN. 
Herman ES and McChesney RW (2000) The global media. In: Held D and McGrew A (eds) The Global Transformations Reader. Cambridge: Polity Press, pp. 216-229.

Hoffman B (2007) Terrorismus - Der unerklärte Krieg. Bonn: Bundeszentrale für politische Bildung.

Huntington SP (1998) Clash of Civilisations and the Remaking of World Order. New York: Simon \& Schuster.

IP International Marketing Committee (2008) Television 2008. International Key Facts. Köln: IP Network.

Iskandar A (2007) Lines in the sand: Problematizing Arab media in the post-taxonomic era. Arab Media \& Society 2007: 1-47. Online under http://www.arabmediasociety.com/articles/downloads/20070523153324_ams2_adel_iskandar.pdf

Ivanova A, Schäfer MS and Schmidt A (forthcoming) Global climate change, global public sphere? In: Canel J and Voltmer K (eds) Comparing Political Communication Across Time and Space: New Studies in An Emerging field. London: Palgrave.

Jasperson AE and El-Kikhia MO (2003) NN and al Jazeera's media coverage of America's war in Afghanistan. In: Norris P, Kern M and Just M (eds) Framing Terrorism: The News Media, the Government and the Public. New York: Routledge, pp. 113-132.

Kelly MJ and Mitchell TH (1981) Transnational terrorism and the western elite press. Political Communication 1: 269-296.

Khalil A, Kadri R and Meyer J (2005) Suicide attacks kill at least 57 at 3 hotels in Jordan's capital. LA Times Online, 11 October 2005. Available at: http://articles.latimes.com/2005/nov/10/ world/fg-bombings 10

Krotz F (2005) Von Modernisierungs- über Dependenz- zu Globalisierungstheorien. In: Hepp A (ed) Globalisierung der Medienkommunikation. Wiesbaden: Verlag für Sozialwissenschaften, pp. 21-43.

Ksiazek TB and Webster JG (2008) Cultural proximity and audience behavior: The role of language in patterns of polarization and multicultural fluency. Journal of Broadcasting \& Electronic Media 52(3): 485-503.

Küng-Shankleman L (2000) Inside the BBC and CNN. London: Routledge.

Lieberson S (1991) Small N's and big conclusions: an examination of the reasoning in comparative studies based on a small number of cases. Social Forces 70: 307-320.

Liebes T and First A (2003) Framing the Israeli-Palestinian conflict. In: Norris P, Kern M and Just M (eds) Framing Terrorism: The News Media, the Government and the Public. New York: Routledge, pp. 59-74.

Löffelholz M and Hepp A (2002) Transkulturelle Kommunikation. In: Hepp A and Löffelholz M (eds) Grundlagentexte zur transkulturellen Kommunikation. Konstanz: UVK, pp. 11-36.

Luhmann N (1997) Die Gesellschaft der Gesellschaft. Frankfurt a.M.: Suhrkamp.

Lynch M (2003) Beyond the Arab street: Iraq and the Arab public sphere. Politics and Society 31: 55-91. Lynch M (2006) Voices of the New Arab Public. Iraq, Al-Jazeera, and Middle East Politics Today.

New York: Columbia University Press.

Mayring P (1994) Qualitative Inhaltsanalyse. Weinheim: Deutscher Studienverlag.

Mermin J (1999) Conflict in the sphere of consensus. Critical reporting on the Panama invasion and the Gulf war. Political Communication 13(2): 181-194.

Meyer JW (2005) Weltkultur. Wie die westlichen Prinzipien die Welt durchdringen. Frankfurt a. M.: Suhrkamp. 
Miles H (2005) How Arab TV News Challenged the World. London: Abacus.

Müller C (2008) Sorgen um den globalen Terrorismus in Deutschland. DIW Wochenbericht 2008: 544-548.

Münkler H (2005) The New Wars. Cambridge: Polity Press.

Nacos BL (2007) Mass-mediated Terrorism: The Central Role of the Media in Terrorism and Counterterrorism. Lanham: Rowman \& Littlefield.

New York Times (2005) Bombings in Amman. Available at: www.nytimes.com/packages/khtml/ 2005/11/10/international/20051110_JORDAN_AUDIOSS.html

Norris P, Kern M and Just M (2003) Framing terrorism. In: Norris P, Kern M and Just M (eds) Framing Terrorism: The News Media, the Government and the Public. New York: Routledge, pp. 3-26.

Nossek H (2004) Our news and their news. Journalism 5: 343-368.

Nossek H (2008) News media-media events: Terrorist acts as media events. Communications 33: $313-330$.

Oates S (2006) Comparing the politics of fear: The role of terrorism news in election campaigns in Russia, the United States and Britain. International Relations 20: 425-437.

Office of Communications (2008) Public Service Broadcasting. Annual Report.

Papacharissi Z and de Fatima Oliveira M (2008) News frames terrorism: A comparative analysis of frames employed in terrorism coverage in U.S. and U.K. Newspapers. Harvard International Journal of Press/Politics 13: 52-74.

Pew Research Center (2004) News Audiences Increasingly Politicized. Washington: Pew Research Center.

Pew Research Center (2005) Project for Excellence in Journalism. The State of the News Media 2005. Washington: Pew Research Center.

Pew Research Center (2006) Project for Excellence in Journalism. The State of the News Media 2006. Washington: Pew Research Center.

Rand Corporation (2009) Database of Worldwide Terrorism Incidents. Online under www.rand. org/nsrd/projects/terrorism-incidents.html

Rapoport DCs (2006) Terrorism: Critical Concepts in Political Science. London: Routledge.

Reese SD and Lewis SC (2009) Framing the War on TerrorThe internalization of policy in the US press. Journalism 10(6): 777-779.

Ritchie J and Lewis J (eds) (2003) Qualitative Research Practice. A Guide for Social Science Students and Researchers. London: Sage.

Robinson P (2001) Theorizing the influence of media on world politics. Models of media influence on foreign policy. European Journal of Communication 16: 523-544.

Rössler P (2004) Political communication messages: Pictures of our world on international television news. In: Esser F and Pfetsch B (eds) Comparing Political Communication: Theories, Cases, and Challenges. Cambridge: University Press, pp. 271-292.

Rugh WA (2007) Do national political systems still influence Arab media? Arab Media \& Society: pp. 1-21. Online under http://www.arabmediasociety.com/?article=225 May.

Schäfer MS (2007) Wissenschaft in den Medien. Die Medialisierung naturwissenschaftlicher Themen. Wiesbaden: Verlag für Sozialwissenschaften.

Schaefer TM (2003) Framing the US Embassy bombings in African and US newspapers. In Norris P, Kern M and Just M (eds) Framing Terrorism: The News Media, the Government and the Public. New York: Routledge, pp. 93-112. 
Scheufele DA, Nisbet MC and Ostman RE (2005) September 11 news coverage, public opinion, and support for civil liberties. Mass Communication \& Society 8: 197-218.

Schmidt A, Ivanova A and Schäfer MS (2013): Media attention for climate change around the world: A comparative analysis of newspaper coverage in 27 countries. Global Environmental Change. Online First under http://www.sciencedirect.com/science/article/pii/S095937801300126X

Schneckener U (2006) Transnationaler Terrorismus. Frankfurt a.M.: Suhrkamp.

Seib P (2004) The news media and the "Clash of Civilizations". Parameters 34(Winter): 71-85.

Selber GM and Ghanem SI (2004) Modernization and media in the Arab World. Global Media Journal 3(5): Article No. 10. Available at: http://lass.purduecal.edu/cca/gmj/fa04/ gmj-fa04-selber-ghanem.htm

Shoemaker PJ and Reese SD (1995) Mediating the Message: Theories of Influence on Mass Media Content. New York: Longman.

Siebert FS, Peterson T and Schramm W (1963) Four Theories of the Press. Chicago: University of Illinois Press.

Strauss AL (1987) Qualitative Analysis for Social Scientists. Cambridge: Cambridge University Press.

Swanson DL (2003) Transnationale politische Kommunikation: Konventionelle Sichtweisen und neue Realitäten. In: Esser F and Pfetsch B (eds) Politische Kommunikation im internationalen Vergleich. Opladen: Westdeutscher Verlag, pp. 56-77.

The White House (2001) Address to a Joint Session of Congress and the American People. Washington: The White House.

Thomaß B (ed) (2007) Mediensysteme im internationalen Vergleich. Konstanz: UVK.

Thompson JB (2000) The globalization of communication. In: Held D and McGrew A (eds) The Global Transformations Reader. Cambridge: Polity Press, pp. 246-295.

Townshend C (2002) Terrorism: A Very Short Introduction. Oxford: Oxford University Press.

Tuman JS (2003) Communicating Terror. The Rhetorical Dimensions of Terrorism. London: Sage.

UN General Assembly (2006) Uniting against terrorism: recommendations for a global counter-terrorism strategy. Report of the Secretary-General (Sixtieth session, Agenda items 46 and 120). New York: United Nations.

Unz D, Schwab F and Winterhoff-Spurk P (2008) TV news - the daily horror? Emotional effects of violent tv news. Journal of Media Psychology 20: 141-156.

Weimann G and Brosius HB (1991) The newsworthiness of international terrorism. Communication Research 18: 333-354.

Weischenberg S (1992) Journalistik. Theorie und Praxis aktueller Medienkommunikation; Bd. 1: Mediensysteme, Medienethik, Medieninstitutionen. Opladen: Westdeutscher Verlag.

Weischenberg S (1995) Journalistik. Theorie und Praxis aktueller Medienkommunikation; Bd. 2: Medientechnik, Medienfunktionen, Medienakteure. Opladen: Westdeutscher Verlag.

Willacy M (2005) Police question dozens over Egypt bombings. ABC News, 25 July 2005.

Williams P (2004) Who's making UK foreign policy? International Affairs 80: 909-929.

Wimmel A (2006) Transnationale Diskurse in Europa. Der Streit um den Türkei-Beitritt in Deutschland, Frankreich und Großbritannien. Frankfurt a. M.: Campus.

Wirth W (2000) Infotainment: Chancen für die politische Sozialisation Jugendlicher? In: Paus-Haase I, Schnatmeyer D and Wegener C (eds) Information, Emotion, Sensation: Wenn im Fernsehen die Grenzen zerfließen. Bielefeld: GMK, pp. 62-91. 
Woods J (2007) What we talk about when we talk about terrorism: Elite press coverage of terrorism risk from 1997 to 2005. Harvard International Journal of Press/Politics 12: 3-20.

Zubayr C and Geese S (2009) Die Informationsqualität der Fernsehnachrichten aus Zuschauersicht. Media Perspektiven 4: 158-173.

Zubayr C and Gerhard H (2009) Tendenzen im Zuschauerverhalten. Media Perspektiven 4: 98-112. 